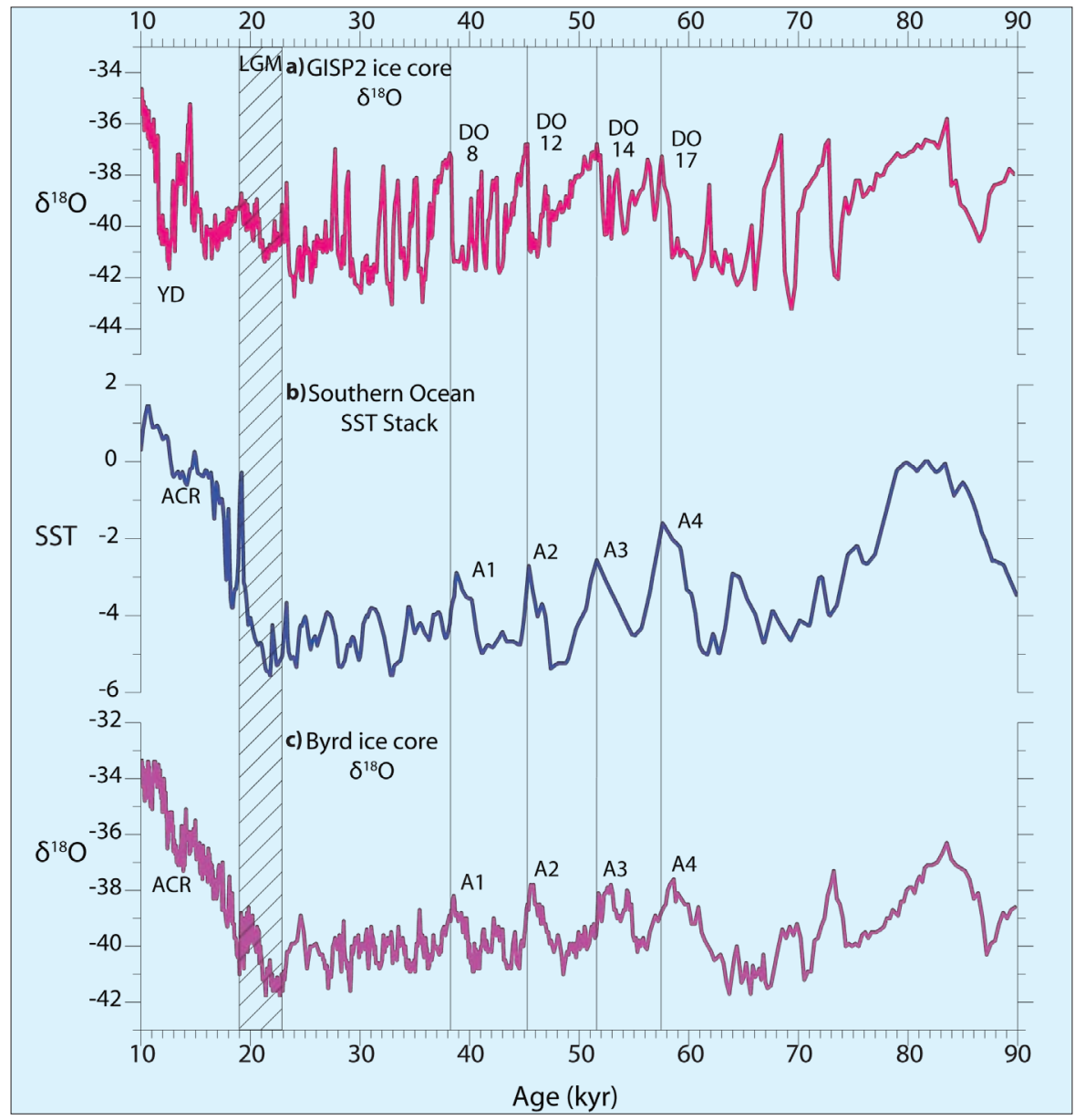

Figure 2: a) Comparison between the GISP 2 oxygen isotope record (Grootes et al., 1993) on the Meese et al. (1997) timescale; b) Southern Ocean SST stack; and c) Byrd ice core oxygen isotope record (Johnsen et al., 1972) on the Blunier and Brook (2001) GISP2 timescale. Note the similar shape shared by the two southern records compared to the northern one. $L G M=$ last glacial maximum (19-23 kyr), $A C R=$ Antarctic Cold Reversal, YD=Younger Dryas Chronozone cooling event. From Barrows et al. (2007).

are studying two cores with high sedimentation rates offshore of the mouth of the Murray River, which drains part of the vast Murray-Darling Basin $\left(\sim 1.10^{6} \mathrm{~km}^{2}\right)$. These cores (especially MD03-2611) promise to provide a link between difficult-to-date ing of glacial periods through time (Pelejero et al., 2006). Work is continuing on this core to develop a higher resolution SST record from planktonic foraminifera and to complete a pollen record that will allow us to study vegetation changes in Tasmania over the last half a million years.

Clearly, climate change is more complicated in the southern hemisphere than originally thought. Although we march to the beat of the same drum as the northern hemisphere, over timescales greater than $20 \mathrm{kyr}$, regional climate in the southern hemisphere has its own melody.

\section{Note}

A full list of references to the data referred to above can be found in Barrows et al. (2007). The above research contributes to the $\mathrm{PASH} 2$ project. Dates from this paper can be obtained from the World Data Center-A for Paleoclimatology.

\section{References}

Barrows, T.T. and Juggins, S., 2005: Sea-surface temperatures around the Australian margin and Indian Ocean during the Last Glacial Maximum, Quaternary Science Reviews, 24: 1017-1047.

Barrows, T.T., Juggins, S., De Deckker, P., Calvo, E. and Pelejero, C., 2007 : Long-term sea-surface temperature and climate change in the Australian-New Zealand region, Paleoceanography, 22: PA 2215 doi:10.1029/2006PA001328.

Gingele, F.X., De Deckker, P. and Hillenbrand, C.-D., 2004: Late Quaternary terrigenous sediments from the Murray Canyons area, offshore South Australia and their implications for sea level change, palaeoclimate and palaeodrainage of the Murray-Darling Basin, Marine Geology, 212: 183-197.

Gingele, F.X., De Deckker, P. and Norman, M., 2007: Late Pleistocene and Holocene climate of SE Australia reconstructed from dust and river loads deposited offshore the River Murray Mouth, Earth and Planetary Science Letters, 255: 257-272.

Pelejero, C., Calvo, E., Barrows, T.T., Logan, G.A. and De Deckker, P., 2006 South Tasman Sea alkenone palaeothermometry over the last four glacial/interglacial cycles, Marine Geology, 230(1-2): 73-86.

deposited offshore (Gingele et al., 2004, 2007). Preliminary results from FR1/94GC3 offshore from Tasmania-spanning the last $450 \mathrm{kyr}$ - provide an SST record that clearly points to a progressive warm-
For full references please consult:

www.pages-igbp.org/products/newsletter/ref2007_2.htm

\title{
Dynamic Antarctic Ice: Agent for Mid-Pleistocene Transition
}

\section{Jim M. Bowler And Mike SANDiford}

School of Earth Sciences, University of Melbourne, Australia; jbowler@unimelb.edu.au

In the record of Plio-Pleistocene climatic evolution, the Antarctic Ice Sheet is generally seen as a passive response to global change, rather than an active agent in its own right. While changes in global relief, particularly the uplift of the Qinghai-Tibet Plateau, are accepted as major drivers into cold, full-glacial $100 \mathrm{kyr}$ cycles (Ruddiman and Kutzbach, 1989; An et al., 2001), the potential influence of change in the Antarctic ice cap has largely escaped attention. The southern Australian coastline, facing the Antarctic continent with some $3000 \mathrm{~km}$ of unbroken fetch, is ideally placed to record changes in Southern Ocean dynamics. As the pattern of travel- ling cyclonic depressions that control the westerly flow across southern Australia reflects steep thermal gradients around the Antarctic margin, the winds and wave regimes impacting southern Australia can be linked to thermal conditions at the Antarctic margin. Changes in one of these systems imply correlative changes in the other. Here, we argue that evidence for dramatic mid-Pleistocene change in Southern Ocean dynamics is present in a remarkable succession of stranded shorelines in the Murray Basin in southeastern Australia, that provides a more-or-less complete record of paleoshorelines deposited over the last 6 Myr (Fig.1a).

\section{The Murray Basin record}

Situated in a relatively stable context, the Murray Basin has acted as an epeiric (epicontinental) sea controlled by the Southern Ocean for some 40 Myr. A mid-Miocene regression (12-7 Myr) was followed by an Upper Miocene transgression (6.5-6 Myr) with the maximum late Neogene marine incursion typically extending inland to heights $\sim 60 \mathrm{~m}$ above present day sea level (Brown and Stephenson, 1991). Regression from Upper Miocene through Pliocene to present time has left more than 170 shore parallel strandline ridges extending from $500 \mathrm{~km}$ inland from the present coast near Naracoorte (Fig. 1b,c). For some 200 km 


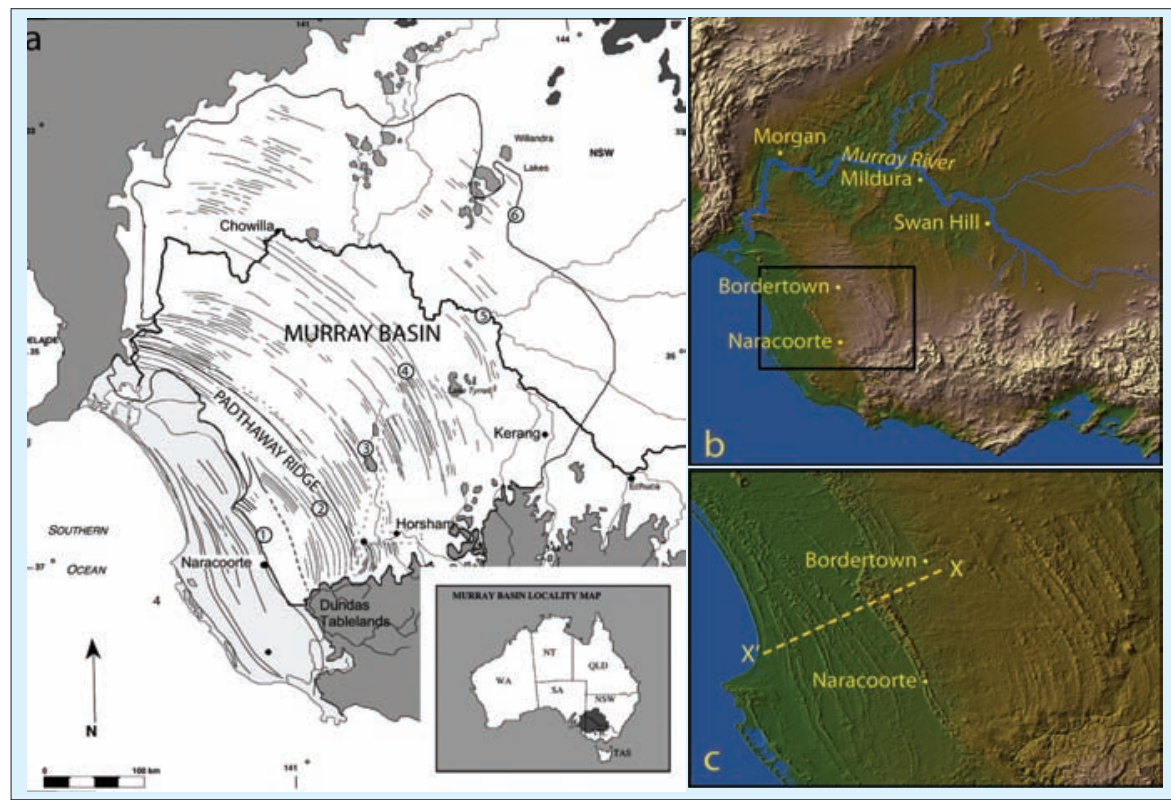

Figure 1: a) Extent of Upper Miocene marine invasion in the Murray Basin, southeastern Australia. Multiple strandline ridges represent legacy of Plio-Pleistocene marine regression falling from near $60 \mathrm{~m}$ to present sea level. The Padthaway Ridge controlled early Pleistocene levels on a rising platform with successive interglacial levels separated laterally on uplifted platform (modified from Kotsonis, 1999). Numbers 1 to 6 represent estimated position of coastline 1-6 Ma; $\boldsymbol{b}$ ) Shaded relief image of the Murray Basin derived from the Shuttle Radar (SRTM) 3 arcsecond topographic data. The green to brown colour transition defines the $60 \mathrm{~m}$ contour and corresponds to the former extent of a Plio-Pleistocene lake (Lake Bungunnia) formed by tectonic depression following retreat of the sea; $\mathbf{c}$ ) Detail of the area of transition between inland Parilla siliceous strandlines and the calcarenite beach ridges of Mid-Pleistocene age near Naracoorte. For detail, see Fig. 2.

inland of Naracoorte, gentle uplift on the NW-SE trending Padthaway Ridge (Fig. 1a), simultaneous with coastal retreat, has separated younger ridges and uplifted older ones (Fig. 1c). At Naracoorte, ridges dated to near the Brunhes-Matuyama boundary (780 kyr) now lie at $+70 \mathrm{~m}$, evidencing uplift at $\sim 60 \mathrm{~m} /$ Myr (Murray-Wallace et al., 2001).

The 6 Myr record of retreating coastlines across the Murray Basin strandplain preserves two distinctive sedimentary associations. The older Pliocene sequence of siliceous near-shore sands of the Parilla Formation grade offshore into shallowwater fossiliferous marls of the Bookpurnong Formation (Brown and Stephenson, 1991). The differential elevation between near-shore sands and offshore marls provides a measure of wave-base that rarely exceeds 40-50 m. By contrast, modern storm waves with periodicity in the 12-14 $s$ range are characterized by a wave-base in excess of $100 \mathrm{~m}$ depth. The younger Pleistocene sequence of shorelines is reflected in large calcarenite back-beach linear dunes of the Bridgwater Formation, and associated downwind parabolic dune fields, both of which continue to deposit along southwest facing ocean beaches to this day. The changes in shoreline facies, from the lower energy siliceous Parilla Sands to calcarenite ridges of the Bridgewater Formation, occur in the BordertownNaracoorte area, and bear witness to a major change in Southern Ocean wind-wave regimes. Intriguingly, the modern inter-
The mid-Pleistocene transition

The onset of Bridgewater facies in the 1.3-1.4 Myr time range poses significant questions for the mid-Pleistocene 100 kyr transition (MPT). The appearance of distinctive calcarenite facies involving an abrupt increase in wave-base with associated shelf abrasion reflects a significant increase in controlling Southern Ocean wind and wave regimes. With Australia's coastal climate so closely tied to high latitude thermal gradients, any major change in controlling Southern Ocean pressure systems points to a change in those controlling regimes; changes that almost certainly involved dynamics of the Antarctic ice cap.

The following interpretation of events is proffered: oscillating patterns on a progressively falling Murray Basin sea level with equivalent isotope reflection defines progressive but oscillatory Pliocene growth of Antarctic ice under warmer and, presumably, wetter conditions than prevail today. After sea level stabilized near present interglacial levels by $2.5 \mathrm{Myr}$, northern hemisphere ice controlled major changes; Antarctica remained relatively stable in terms of total ice volume. The subsequent transition to a base frozen ice sheet, with development of a sea-ice girdle, leaves virtually no signature in the eustatic record, but enhances surrounding thermal gradients and leads to changes in Southern Ocean dynamics. The increased coastal energy reflected in the transition from Parilla to Bridgewater thereby points directly to amplified cooling in the circumAntarctic region.

Significantly, this change precedes the MPT by some 300-400 kyr. Once established, such amplified cooling offers two effects. Firstly, it strengthens the control of $\sim 41$ kyr obliquity signal by effectively dampening weaker precessional effects. Secondly, by acting in the new role as a global thermostat, the now super-cold ice cap also becomes capable of dampening the power of obliquity insolation to full interglacial levels. This process would effectively favor development of $100 \mathrm{ka} \mathrm{cy}$ cles, a process anticipated by Ruddiman's (2003) hypothesis for the explanation of the MPT.

The Murray Basin evidence points directly to the role of a highly dynamic ice cap controlling elements of both sea level and climatic evolution, not only in this region of the Southern Ocean but with implications of wider global significance. Far from a simple passive response to global change, it suggests that the Antarctic ice cap has played a much more active role than previously recognized. Improved ridges involves correlation with stron interglacial peaks immediately preceding MIS 25. This would place ages of oldest Bridgewater Formation ridges within the range MIS 43-47 near 1.3-1.4 Myr. This estimate, together with intermediate spacing between ridges, is consistent with dominant 40 kyr controls in both data sets at this time (Fig. 2). 


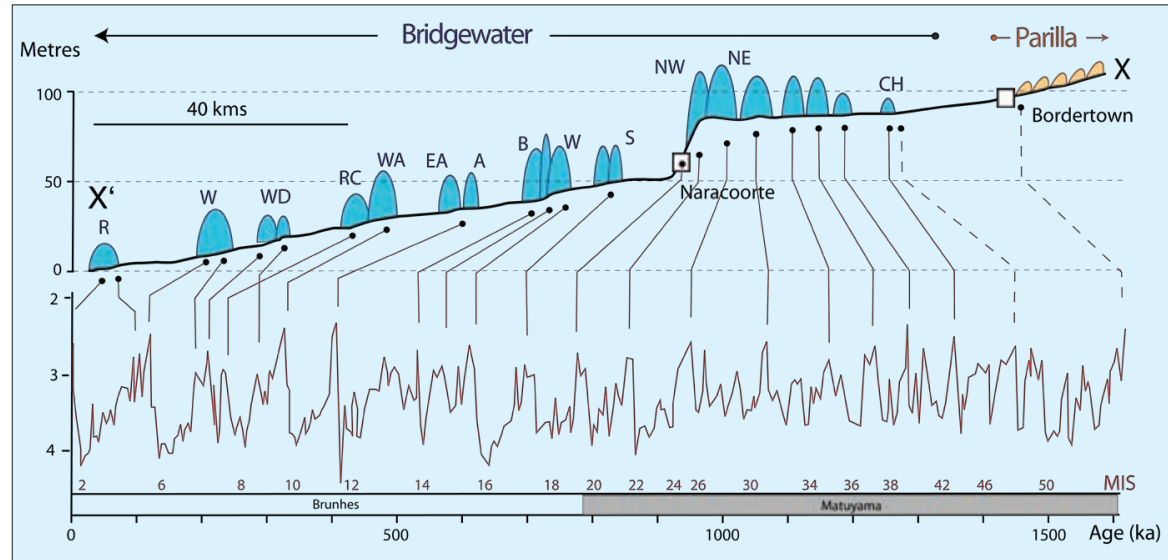

Figure 2: Correlation of the strandline-coastal ridge system (along profile line X'-X in Fig. Ic from near Kingston via Naracoorte to Bordertown) with marine isotopic interglacial peaks based on the chronology of Tian et al, 2002. Ridge sequence and isotope correlation, Naracoorte to coast from Murray-Wallace et al., 2001. The age of the oldest Bridgewater ridge is tentatively correlated with isotope stages 43 or 47, dated to near 1.3-1.4 Myr ago. Beachridge names: (CH) Cannonball Hill, (NE) Naracoorte East, (NW) Naracoorte West, (S) Stewart, (W) Woolumbool, (B) Baker, (A) Ardune, (EA) East Avenue, (WA) West Avenue, (RC) Reedy Creek, (WD) West Diary, (W) Woakwine, (R) Robe (Murray-Wallace et al., 2001). understanding of that role presents new challenges in modeling predictions of future greenhouse responses.

\section{References}

Brown, C.M. and Stephenson, A.E., 1991: Geology of the Murray Basin, Southeastern Australia, Bureau of Mineral Resources Bulletin, 235.

Kotsonis, A. 1999: Tertiary shorelines of the western Murray Basin: weathering, sedimentology and exploration potential. In: Stewart, R. (Ed) Murray Basin Mineral Sands Conference, Australian Institute of Geoscientists Bulletin, 26: 57-63.

Murray-Wallace, C.V., Brooke, B.P., Cann, J.H., Belperio, A.P. and Bourman, R.P., 2001: Whole-rock aminostratigraphy of the Coorong Coastal Plain, South Australia: towards a million year record of sea-level highstands, Journal of the Geological Society of London, 158 $111-124$.

Ruddiman, W.F., 2003: Orbital insolation, ice volume, and greenhouse gases, Quaternary Science Reviews, 22: 1597-1629.

Tian, J., Wang, P. X., Chen, X. and Li, Q. U., 2002: Astronomically tuned Plio- Pleistocene benthic $\partial^{18} 0$ record from South-China Sea and Atlantic-Pacific comparison, Earth and Planetary Science Letters, 203: 1015-1029.

\section{NZ-Maars: Extracting high resolution paleoclimate} records from maar crater lakes, Auckland, New Zealand

Paul Augustinus

School of Geography, Geology and Environmental Science, University of Auckland, New Zealand; p.augustinus@auckland.ac.nz

\section{Introduction}

An understanding of the mechanics of past climate change is a powerful tool for managing the consequences of present and future climate variability. However, the high-resolution records of climate change needed to determine the forces driving this variability are typically limited to the duration of the instrumental record. The short duration of that record in New Zealand (little more than 100 years) means that we have limited insight into the operation of the climate system under earlier and different climate scenarios, so that we need to use geological data sets to reconstruct past climates (Shulmeister et al., 2006). However, most geological datasets have a resolution of millennia to centuries at best, too coarse for integration with climate systems operating on timescales of months to decades. Hence, the NZ-Maar project was established to exploit the high-resolution paleoclimate records contained in laminated maar lake sediment sequences from Auckland, northern New Zealand (Fig. 1).

The Auckland region has a dense cluster of about 48 basaltic volcanoes, mostly tuff rings and scoriaceous cinder cones, all within Auckland City, New Zealand's largest and most densely populated center (Fig. 1). In addition, there are a number of maar craters, each of which has been a lake some time after its formative eruption, and several of which have been cored to extract records of sedimentation and

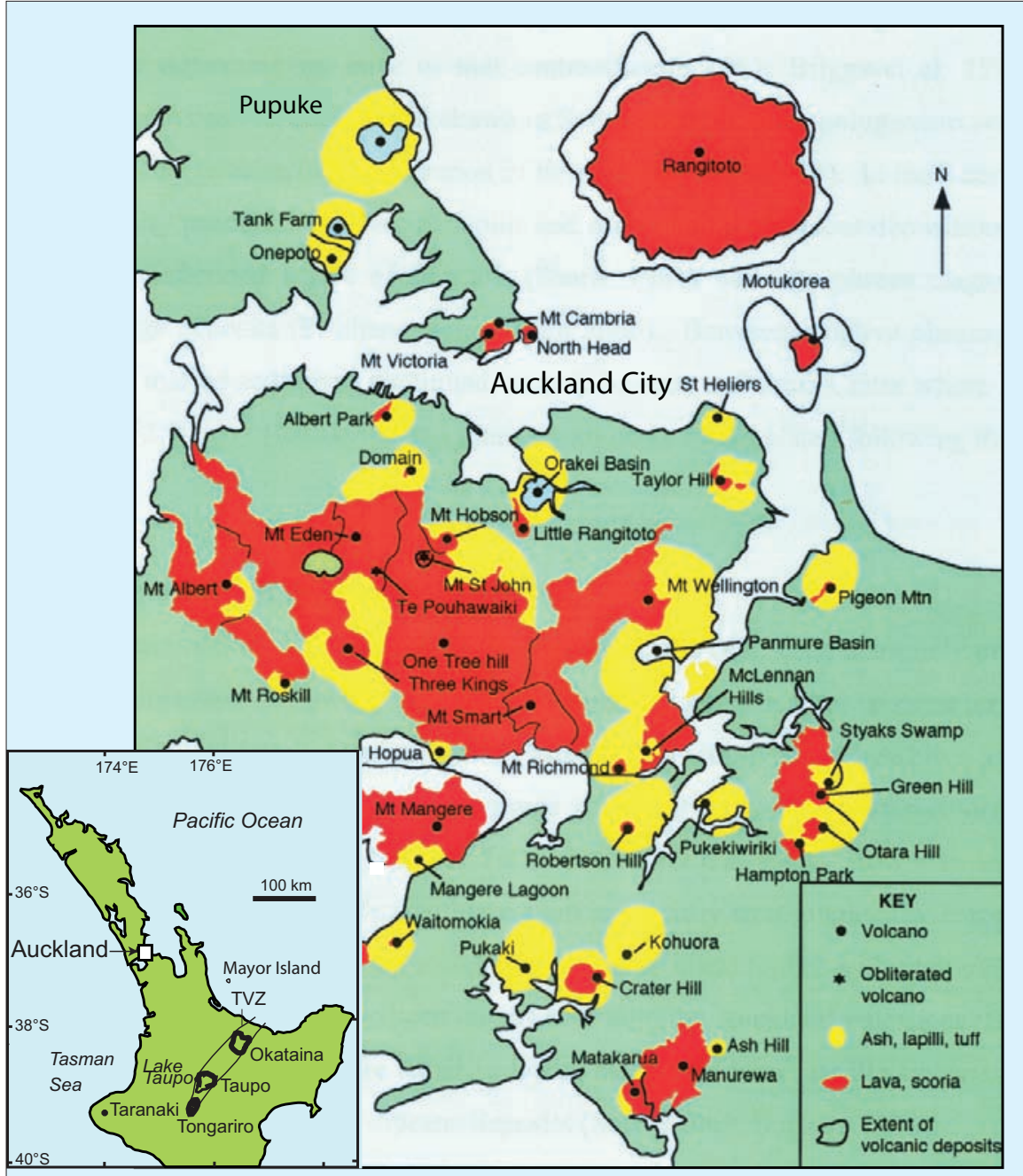

Figure 1: Location map showing Auckland basaltic cones and maar craters. Inset andesitic and rhyolitic tephra sources and volcanic setting of study area (TVZ - Taupo Volcanic Zone) (modified from Alloway et al., 2007). 